\title{
UPAYA PIMPINAN KOMISARIAT PERGURUAN TINGGI IPNU IPPNU DALAM PENCEGAHAN RADIKALISME DI KAMPUS
}

\author{
Novi Afri Riati \\ Progam Studi PAI FTIK IAIN Jember \\ noviafri93@gmail.com \\ Imron Fauzi \\ Progam Studi PAI FTIK IAIN Jember \\ imronfauzi@iain-Jember.ac.id
}

\begin{abstract}
ABSTRAK
Radikalisme adalah suatu aliran yang mempunyai keinginan perubahan pembaharuan sosial dan politik dengan cara kekerasan. seperti anarkisme, dalam kondisi ini masih dalam tahap pemikiran, inilah yang dikhawatirkan jika radikalisme menyebar di kampus Untuk mengantisipasi PKPT IPNU IPPNU organisasi di kampus IAIN Jember berupaya membentengi faham radikalisme. Untuk menanamkan nilai-nilai ke-Aswaja-an agar pemikiran mahasiswa tidak mudah terpengaruh oleh kaum radikalis. Penelitian ini menggunakan pendekatan kualitatif, Jenis penelitian yang digunakan adalah penelitian studi kasus, teknik pengumpulan data dalam penelitian ini menggunakan wawancara, observasi dan dokumenter, sedangkan analisis data yang digunakan adalah kondensasi data, penyajian data, dan penarikan kesimpulan. Keabsahan data yang digunakan adalah adalah triangulasi sumber dan triangulasi teknik. Penelitian ini memperoleh kesimpulan 1) indentifikasi radikalisme antara lain orang yang menganggap dirinya paling baik dan benar sendiri, menegakkan khilafah Islamiyah, berfikir tekstual, tidak menghargai perbedaan, tidak memandang keberagamaan, menolak moderasi agama, anti NKRI dan Pancasila. 2) Bentuk kegiatan PKPT IPNU IPPNU IAIN Jember dalam pecegahan radikalisme MAKESTA, (masa kesetiaan anggota) LAKMUD (latihan kader muda) Sholawatan, peringatan hari besar seperti Isra'Mi'roj, ziarah ke makam para wali. setiap malam jum'at Tahlilan, tiba'an, kajian mengenai kitab Arbain Nawawi, Ke-NUan, membahas isu-isu yang telah viral. 3) Faktor pendukung Internal kerja sama saling komunikasi pembina mengarahkan pengurus. Faktor penghambat internal, kurang saling komunikasi pengurus, anggota, pembiayaan sangat minim. Faktor pendukung Eksternal, bascampe, gedung, kelas, serambi Masjid. media sebagai sarana dakwah Faktor penghambatnya Eksternal tidak dapat pinjaman gedung.
\end{abstract}

Kata kunci : Radikalisme, IPNU IPPNU, Aswaja

\begin{abstract}
Radicalism is a flow that has a desire to change social and political renewal in a violent way. Like anarchism, in this condition is still in the stage of thought, that way it feared if radicalism spreads on campus to anticipate PKPT IPNU IPPNU organization on campus IAIN Jember seeks to fortify the understand radicalism. To embed the values of the Aswaja so that students ' thinking is not easily affected by the radicalists. The study uses a qualitative approach, the type of research used is case
\end{abstract}




\section{AL- ADABIYAH: Jurnal Pendidikan Agama Islam}

study research, the data collection techniques in this study using interviews, observations and documentaries, while the data analysis used is data condensation, data presentation, and withdrawal conclusions. The validity of the data used is the source triangulation and the triangulation technique. The study obtained the conclusion 1) the identification of radicalism indicators among others who consider themselves best and true themselves, uphold Islamiyah Caliphate, think textual, do not appreciate the distinction, not to view its efficacy, reject religious moderation, anti NKRI and Pancasila. 2) The activity of PKPT IPNU IPPNU IAIN Jember in MAKESTA Pecegahan radicalism, (Member loyalty period) LAKMUD (training of young cadres) shovisit, a memorial Day such as Isra'mi 'Roj, a pilgrimage to the tomb of the Guardians. Every Friday night Tahlilan, Tiba'an, study of the book Arbain Nawawi, Ke-NUan, discusses issues that have been viral. 3) Internal supporting factor of mutual communication of the coach directs the caretaker. Internal inhibiting factor, less communication between admins, members, financing is minimal. External supporting factors, Bascampe, building, class, porch of the mosque. Media as a means of propagation factor external is unable to loan the building.

Key words: Radicalism, IPNU IPPNU, Aswaja

\section{Pendahuluan}

Nahdlatul Ulama (NU) adalah organisasi keagamaan, wadah bagi para ulama dan para pengikutnya yang didirikan pada tanggal 16 Rajab $1344 \mathrm{H}$ bertepatan dengan 31 Januari 1926 M di Surabaya. NU yaitu sebagai suatu gerakan keagamaan yang mempunyai tujuan untuk membangun dan mengembangkan insan masyarakat yang bertaqwa kepada Allah SWT dan mencerdaskan generasi muda dengan mempunyai banyak ketrampilan serta berahlak mulia, tentram, adil dan sejahtera (Muzadi, 2006: 4). Sejak didirikan Nahdlatul Ulama cita-cita dan langkah-langkahnya bertumpu pada gerakan islah yaitu perbaikan dan peningkatan kebaikan, dilandasi oleh sikap masyarakat Nahdlatul Ulama yang oleh Ahmad Siddiq dirumuskan ke empat sikap yaitu pertama, sikap tawasuth dan i'tidal, tasamuh, tawazun, Amar ma'ruf nahi munka. Dari keempat sikap tersebut masyarakat dapat dijadikan sebagai panutan dalam melakukan tindakan yang lurus untuk menghindari segala bentuk yang bersifat ekstrim (Bruinessen, 2004: 89).

Di samping itu NU juga memiliki unit kegiatan yang disebut badan otonom, yaitu kegiatan yang bertugas sebagai kelompok tertentu dari kaum Nahdliyyin seperti Muslimat, Fatayat, Ansor, IPNU, IPPNU, ISNU, jam'iyah Qurra' wal haffadz dan sebagainya. Suatu badan otonom memiliki anggota, pengurus, peraturan dasar, peraturan rumah tangga tersendiri, tetapi memiliki hubungan yang jelas dengan NU. Semua lembaga, lajnah dan badan otonom adalah bagian dan alat 


\section{AL- ADABIYAH: Jurnal Pendidikan Agama Islam}

kegiatan yang harus mengikuti kepada NU, semua harus membina menjadi kader NU (Muzadi, 2006: 109). Radikalisme adalah suatu aliran yang mempunyai keinginan perubahan pembaharuan sosial dan politik dengan cara kekerasan. Dari hal seperti inilah yang dikhawatirkan jika radikalisme menyebar di kampus khususnya dikalangan mahasiswa (Larasati, 2018: 3). Radikalisme menurut Saifuddin (2011: 29) bukan sesuatu yang muncul sendiri ditengah-tengah kampus, akan tetapi adanya proses komunikasi dengan jaringan-jaringan diluar kampus, yang belum tentu informasi tersebut sesuai dengan kebenarannya, seperti mendapatkan informasi melalui whatsapp, internet, youtube, instagram, facebook dan lainnya.

Adapun terdapat mahasiswa Universitas Jember (UNEJ) Sebanyak 22 persen yang terpapar radikalisme. teologis, yakni setuju dengan pengkafiran, qital, jihad yaitu sejumlah 25 persen, radikalisme politis berupa kesetujuan pada konsep negara Islam atau khilafah sejumlah 20 persen (Susanto, 2019). Dalam hal ini pernah diintruksikan Institut Agama Islam Negeri Jember. Wakil Rektor Bidang Pengembangan Akademik IAIN Jember Nur Sholikin, pada 6 April 2017 menyatakan, IAIN Jember sudah membuat surat edaran yang telah ditandatangani rektor mengenai pencegahan paham anti NKRI, salah satunya dikeluarkanlah sebuah aturan dalam berbusana oleh Fakultas Tarbiyah, yaitu mahasiswi dilarang memakai cadar saat mengikuti perkuliahan. Menurut Nur Sholikin larangan penggunaan cadar diberlakukan untuk mencegah tumbuhnya paham radikal di kampus (Qodir, 2018: 7).

Sejak awal visi IAIN Jember terutama Prodi PAI menjadi Program Studi PAI terdepan di lingkungan Perguruan Tinggi Islam dalam menyiapkan tenaga pendidik Agama Islam yang sesuai dengan tuntutan dan kebutuhan masyarakat lokal, nasional, regional, dan internasional, dengan memiliki kekokohan akidah dan kedalaman spiritual, keluhuran akhlak dan kematangan profesional. salah satu cara untuk mewujudkan visi di atas adalah mengadakan kajian-kajian keagamaan disesuaikan dengan masalah kekinian sehingga Islam akan selalu relevan di sepanjang zaman. Jika ditelusuri baik pro maupun kontra antara pemikiran mahasiswa diakibatkan dengan keterbatasan literatur yang mereka miliki sehingga dapat meninimbulkan sikap sama-sama ekstrim (Nawangsari, 2009).

Bagi yang pro dalam pemahaman keilmuan yang murni Islam tanpa disertai kedalaman aqidah yang memadai sehingga seringkali membawa mahasiswa ke arah penistaan kepada agama. Sebaliknya bagi yang kontra terlalu berlebihan 


\section{AL- ADABIYAH: Jurnal Pendidikan Agama Islam}

sering terjebak pada sikap menutup diri terhadap pandangan lain berlawanan dengan kebenaran yang mereka yakini, sehingga memunculkan sikap yang kurang ramah bahkan cenderung merusak terhadap pemahaman keagamaan yang berbeda dengan dirinya. Meskipun adanya pro dan kontra antara mahasiswa, mereka sama sekali tidak merasa menyesal menempuh studi di IAIN Jember, mereka tidak merasa menjadi agen-agen Barat untuk merusak Islam. Mereka juga tidak merasa menjadi murtad meskipun mengkaji Islam dengan pendekatan yang berbeda sama sekali dengan pemahaman keagamaan yang khas menurut keyakinan mereka masing-masing (Nawangsari, 2009).

Berdasarkan Undang-Undang Republik Indonesia nomor 5 tahun 2018 tentang pemberantasan tindak pidana terorisme adalah perbuatan menggunakan kekerasan atau ancaman yang menimbulkan suatu teror atau rasa cemas yang dapat menimbulkan gangguan keamanan. Radikalisme saat ini sudah mulai menjadi pengaruh dikalangan masyarakat maupun pemuda zaman sekarang dan sangat cepat menyebar luas, sehingga mempengaruhi seseorang untuk melakukan aksi kekerasan disebabkan karena tidak nyaman dengan situasi negara dan demokrasi yang ada. dengan ini tanpa mereka sadari bahwa sesorang tersebut masuk kedalam ajaran radikalisme.

Sebagai langkah mengantisipasi, terjadinya kekerasan maupun pemahaman mengenai agama dikalangan mahasiswa, PKPT IPNU IPPNU adalah salah satu sebuah organisasi yang ada dikampus IAIN Jember. Yang berupaya untuk membentengi faham Radikalisme, yaitu dengan melakukan kegiatan kegamaan yang dapat menanamkan nilai-nilai ke-Aswaja-an dikalangan mahasiswa agar tidak mudah dimasuki faham-faham tersebut karena faham radikalisme sangat mempengaruhi sikap dan perilaku di kalangan mahasiswa. Dari uraian diatas penting untuk diteliti sehingga peneliti mengangkat tema "Upaya PKPT IPNU IPPNU Dalam Pencegahan Radikalisme di kampus IAIN Jember“ untuk melakukan kegiatan PKPT IPNU IPPNU dalam pencegahan dikampus IAIN Jember. Tujuan dari penelitian ini adalah Untuk mengkaji tentang PKPT IPNU IPPNU mengidentifikasi radikalisme di kampus IAIN Jember. Untuk mengkaji bentuk-bentuk upaya PKPT IPNU IPPNU dalam pencegahan radikalisme di kampus IAIN Jember dan untuk mengkaji faktor pendukung dan penghambat upaya PKPT IPNU IPPNU dalam pencegahan radikalisme di kampus IAIN Jember. 


\section{AL- ADABIYAH: Jurnal Pendidikan Agama Islam}

\section{Tinjauan Literatur}

\section{Nahdlatul Ulama}

Dalam kaitan ini sebagai organisasi yang menjalankan prinsip rahmatan lil 'alamin NU memiliki nilai-nilai operasional yang mengejawantahkan prinsip Islam rahmatan lil 'alamin. Pertama tawasuth. Yakni sikap mengambil jalan tengah ketika berada di dua titik jalan ekstrim (Ulum, 2017: 163). Kedua I'tidal. Sikap adil ini menjadi subtansi, konsistensi, dan akurasi yang senantiasa dijaga di dalam posisi tawasuth, sehingga tawasuth berkaitan dengan posisi, maka i'tidal adalah subtansi yang dijaga di dalam posisi tawasuth tersebut, sikap tawasuth dan I'tidal ini kemudian melahirkan sikap-sikap Nahdliyyin lainnya, yakni tasamuh (toleransi), tawazun (seimbang) dan tasyawur (musyawarah).

Oleh karenanya, di tengah upaya-upaya ideologis yang digerakkan oleh sayap ekstrim seperti komunisme dan gerakan fundamentalis Islam, NU tetap berada di titik tawasuth dan i'tidal, sehingga disetiap fase sejarah kenegaraan RI, sikap NU senantiasa sama, yakni mengawal nilai-nilai keadilan yang menjadi prinsip umat dari syari'at Islam (Ulum, 2017: 164).

Badan otonom NU adalah perangkat Organisasi NU yang berfungsi membantu melaksanakan kebijakan NU khusunya yang berkaitan dengan kelompok masyarakat tertentu yaitu : Muslimat NU, Fatayat NU, GP ANSOR, IPNU, IPPNU, Jami'ah Ahli Thariqoh al-Mu'tabaroh an Nahdliyah, JQH (Jamiyatul Quro' wal hufadz), Pergunu (Persatuan Guru Nahdlatul Ulama) dan ISNU (Ikatan Sarjana Nahdlatul Ulama) (Ulum, 2017: 148).

PKPT singkatan dari pimpinan komisariat perguruan tinggi yaitu merupakan suatu kesatuan organik yang mempunyai kedudukan sebagai pemegang kepemimpinan organisasi ditingkat perguruan tinggi. Beberapa kriteria pengurus komisariat perguruan tinggi adalah umur setingganya 22 tahun, pendidikan serendah-rendahnya SLTA atau sederajat dan pernah mengikuti (Makesta) dibuktikan dengan adanya sertifikat makesta (Hazin, 2019: 24).

Tujuan dari IPNU adalah membentuk pelajar yang bertaqwa kepada Allah SWT, berilmu, berahlak mulia, berwawasan kebangsaan, dan kebhinekaan serta bertanggung jawab atas terlaksananya syariat Islam menurut faham Ahlusunnah Wal jama'ah yang berdasarkan Pancasila dan UUD 1945 (Hazin, 2019: 13). IPPNU mempunyai peran sebagai "garda terdepan kaderisasi" atau 


\section{AL- ADABIYAH: Jurnal Pendidikan Agama Islam}

bisa dikatakan sebagai pintu pertama masuk di NU. Tujuan IPPNU bukan untuk mencari massa akan tetapi untuk mencerdasarkan kader, menciptakan kader yang berilmu, berwawasan, serta mempunyai intelektual yang religius yang berpaham Ahlussunnah wal Jama'ah (Hazin, 2019: 23).

a. Pengertian Radikalisme

Kata Radikal berasal dari bahasa latin "Radix" artinya akar dalam bahasa inggris kata radical dapat bermakna ekstrim, fanatik, menyeluruh dan fundamental. Sedangkan kata radicalism artinya doktrin atau penganut paham radikal atau paham ekstrim (Wahab, 2019: 22). Menurut Kamus Besar Bahasa Indonesia Radikalisme mempunyai arti sebagai paham atau aliran menginginkan suatu perubahan, atau pembaharuan sosial atau politik yang menggunakan kekerasan, sikap ekstrim dalam suatu aliran politik (Zuhri, 2017: 30).

Tiga karakter fenomena radikalisme yang ditulis oleh Horace M. Kallen: pertama, munculnya radikalisme sebagai respons berupa evaluasi, penolakan dan perlawanan atas kondisi yang berlangsung, baik berupa asumsi, nilai bahkan lembaga atau negara. Kedua, radikalisme selalu berupaya mengubah tatanan yang sudah ada dengan tatanan lain melalui pandangan dunia mereka sendiri. Ketiga, keyakinan akan kebenaran ideologi yang sangat kuat yang mereka tawarkan. Dari hal tersebut sangat rentan terjadinya sebuah kekerasan, dan munculnya sikap emosional. Aksiaksi utamanya yang mengancam dan menghendaki perubahan kesepakatan nasional dasar hidup berbangsa dan bernegara seperti Pancasila, UUD Negara RI 1945, Bhineka Tunggal Ika, dan NKRI (Zuhri, 2017: 25).

Menurut NU dalam Tahfidz Muktamar NU Ke 33 Tahun 2015 menyebut empat karakteristik kelompok radikal dan terorisme. Pertama, kelompok Takfiri, Ideologi takfiri bersumber dari ajaran Wahabi yang berkembang di Arab Saudi. Kelompok ini termasuk kelompok paling Ekstrim, kelompok ini paling mudah menganggap kelompok lain yang tidak sejalan dengan label kafir, Kedua, kelompok Jihadi. Ideologi Takfiri sebagai pemicu lahirnya kelompok jihadi. Kelompok ini beranggapan jika sistem negara tidak menggunakan syariat Islam sebagai sistem kafir dan thogut (Zuhri, 2017: 75).

Ketiga, kelompok Siyasi. Kelompok berideologi transnasional yang melalui jalur politik, dari kelompok ini mendirikan partai politik dengan 


\section{AL- ADABIYAH: Jurnal Pendidikan Agama Islam}

menggunakan simbol-simbol Islam. Keempat, kelompok Salafi, yaitu kelompok yang sering menyebarkan ajaran Wahabi, serta menyalahkan orang lain dan menuduh orang lain sebagai pelaku Bid'ah (Zuhri, 2017: 76).

b. Bentuk bentuk radikalimse

1) Pemikiran

Radikalisme masih berupa wacana, konsep dan gagasan yang masih di perbincangkan, yang intinya mendukung penggunaan cara-cara kekerasan untuk mencapai tujuan. Nell J. Smelser menyatakan bahwa berbagai faktor seperti kondisi ekonomi, politik, agama dan lain-lain memang dapat menimbulkan gerakan terorganisir yang terlibat dalam terorisme, namun kondisi tersebut tidak lantas menjamin dilakukannya kekerasan (Musthofa, 2012: 67). Paham radikalisme ini terjadi karena proses Islamisasi yang dilakukan di kalangan anak muda berlangsung secara tertutup, dan cenderung tidak terbuka pada pandangan Islam lainnya, apalagi yang berbeda keyakinannya (Asrori, 2015: 260).

2) Aksi atau tindakan

Radikalisme bisa berada pada ranah sosial-politik dan agama. Pada ranah politik, faham ini tampak tercermin dari adanya tindakan memaksakan pendapatnya dengan cara-cara yang ikonstitusional, bahkan bisa berupa tindakan mobilisasi masa untuk kepentingan politik tertentu dan berujung pada konflik sosial (Munip, 2012: 162).

Perubahan atas Undang Undang Nomor 15 tahun 2003 Tentang Penetapan peraturan pemerintahan pengganti Undang Undang Nomor 1 Tahun 2002 Tentang pemberantasan tindak pidana terorisme menjadi Undang Undang pasal 13A berbunyi setiap orang yang memiliki hubungan dengan organisasi Terorisme dan dengan sengaja menyebarkan ucapan, sikap, atau perilaku, tulisan atau tampilan dengan tujuan untuk menghasut orang atau kelompok orang untuk melakukan kekerasan atau ancaman kekerasan yang dapat mengakibatkan Tindak Pidana Teorisme dipidana dengan pidana penjara paling lama 5 tahun. 


\section{AL- ADABIYAH: Jurnal Pendidikan Agama Islam}

\section{Metode}

Pendekatan yang digunakan dalam penelitian ini adalah pendekatan kualitatif (Margono, 2010: 15). Jenis penelitian yang digunakan adalah penelitian studi kasus. kegiatan yang memperoleh data yang dilakukan dalam konteks kehidupan nyata, karena itu studi kasus sebagai proses mengkaji atau memahami sebuah kasus dan sekaligus mencari hasilnya (Prihatsanti, 2018: 128).

Dalam penelitian ini peneliti menggunakan teknik pengumpulan data yaitu observasi, wawancara dan dokumentasi sebagai berikut. Observasi diartikan sebagai pengalaman dan peralatan secara sistematik terhadap gejala yang tampak pada objek penelitian (Margono, 2010: 58). Dalam hal ini peneliti mengadakan pengamatan secara langsung terhadap gejala-gejala subjek yang diteliti yaitu dengan Participant Observer (Sugiono, 2017: 317). Wawancara yang digunakan dalam penelitian ini adalah wawancara semi struktur, tujuan peneliti menggunakan jenis wawancara ini adalah untuk menemukan permasalahan secara lebih terbuka, dimana pihak yang diwawancara diminta menyampaikan pendapat melalui ide-idenya ((Sugiono, 2017: 133). Dokumenter merupakan catatan peristiwa yang sudah berlaku. Dokumen bisa berbentuk lisan, gambar, atau karyakarya monumental dari seseorang (Yusuf, 2014: 391).

Adapun analisis data peneliti menggunakan teori Milles, Huberman dan Saldana, yaitu sebagai berikut (Miles et al., 2019: 31). Pengumpulan data (data collection) yaitu pengumpulan data pertama atau mentah yang dikumpulkan dalam suatu penelitian. Kondensasi data (data condentation) merupakan proses menyeleksi, memfokuskan, menyederhanakan, dan mengabstraksi serta mengubah catatan lapangan, transkip wawancara, dokumen dan temuan empirik lainya, letak perbedaan antara kondensasi data dengan reduksi data adalah terletak pada cara penyederhanaan data. Cenderung memilah sedangkan kondensasi menyesuaikan seluruh data yang dijaring tanpa harus memilah (mengurangi data). Penyajian data (data display) Dalam penelitian ini penelitian data dapat dilakukan dalam bentuk urain singkat. yang sering digunakan untuk menyajikan data dalam penelitian kualitatif adalah dengan teks yang bersifat naratif. Dengan menggunakan penyajian data yang akan memudahkan peneliti untuk memahami apa yang telah terjadi, merencanakan kegiatan selanjutnya berdasarkan apa yang telah dipahami. Penarikan kesimpulan ( conclusion drawing/verification ) adalah kesimpulan yang 


\section{AL- ADABIYAH: Jurnal Pendidikan Agama Islam}

awal masih bersifat sementara, akan berubah apabila ada bukti-bukti yang kuat yang mendukung pada tahap berikutnya. Kesimpulan dalam penelitian kualitatif dapat menjawab rumusan masalah yang telah dirumuskan sejak awal tetapi mungkin juga tidak karena rumusan masalah dalam penelitian kualitatif bersifat sementara (Miles et al., 2019: 33.

\section{Hasil dan Diskusi}

\section{PKPT IPNU IPPNU mengidentifikasi radikalisme di kampus IAIN Jember}

Berdasarkan beberapa analisis data bahwa bentuk bentuk radikalisme agama yang ada di kalangan mahasiswa IAIN Jember masih umum tidak terlihat, karena secara sistematik radikalime tidak ada bahkan dilarang di IAIN Jember, akan tetapi dari segi individual secara keyakinan ada dan itu sulit terdeteksi, karena bisa jadi itu mahasiswa mendapatkan pemahaman IAIN Jember yang mengikuti kajian di luar kampus.

Tiga karakter fenomena radikalisme yang ditulis oleh Horace M. Kallen: pertama, munculnya radikalisme sebagai respons berupa evaluasi, penolakan dan perlawanan atas kondisi yang berlangsung, baik berupa asumsi, nilai bahkan lembaga atau negara. Kedua, radikalisme selalu berupaya mengubah tatanan yang sudah ada dengan tatanan lain melalui pandangan dunia mereka sendiri. Ketiga, keyakinan akan kebenaran ideologi yang sangat kuat yang mereka tawarkan. Dari hal tersebut sangat rentan terjadinya sebuah kekerasan, dan munculnya sikap emosional. Aksi-aksi utamanya yang mengancam dan menghendaki perubahan kesepakatan nasional dasar hidup berbangsa dan bernegara seperti Pancasila, UUD Negara RI 1945, Bhineka Tunggal Ika, dan NKRI. Kelompok ini juga sering menggunakan kekerasan sebagai acara untuk memaksa kehendaknya (Zuhri, 2017: 25).

Hasil temuan radikalisme yang dimaksud dalam penelitian ini sesuai dengan terori diatas yang ketiga yaitu mengenai keyakinan akan kebenaran, faktor ideologi merupakan penyebab terjadinya perkembangan radikalisme di kalangan mahasiswa. Mereka dipengaruhi untuk mengikuti kajian diluar kampus,

Radikalisme pemikiran yang masih berupa wacana, konsep, gagasan yang masih diperbincangkan, yang intinya mendukung penggunaan kekerasan untuk mencapai tujuan (Musthofa, 2012: 67). Hasil temuan sesuai dengan teori diatas 


\section{AL- ADABIYAH: Jurnal Pendidikan Agama Islam}

tindakan radikalisme di kalangan mahasiswa IAIN Jember masih belum terlihat, akan tetapi jika dalam ranah pemikiran tentang keyakinan dalam individu seseorang mahasiswa masih ada mereka sifatnya tertutup tidak terbuka, jadi kita tidak bisa langsung menjustifikasi orang tersebut radikal karena kita harus mempunyai bukti yang konkret.

Dengan adanya ditemukannya beberapa mahasiswa yang mengikuti kajian HTI diluar kampus tidak dapat dipungkiri mahasiswa dapat terpapar radikalisme.

Berdasarkan hasil temuan PKPT IPNU IPPNU dalam mengidentifikasi indikator radikalisme dengan batasan yang bertentangan dengan aswaja yaitu orang yang menganggap dirinya paling baik dan benar, menegakan khilafah islamiyah, berfikir tekstual yang dibaca dijadikan keyakinan, tidak menghargai perbedaan, tidak memandang keberagaman, menolak moderasi agama, menolak pluralisme agama, anti NKRI dan Pancasila.

Berdasarkan data di atas peneliti berpendapat bahwa kelompok yang terpapar radikal dapat dibendung agar tidak mudah masuk di kalangan mahasiswa agar tidak menyebar secara luas, walaupun bentuk radikalisme dikampus tidak terlihat karena yang menjadi sasaran adalah mahasiswa, seperti yang kita ketahui bahwa mahasiswa sangat berpengaruh terhadap negara, apabila mereka dikuasai oleh kaum radikalis negara ini akan mengalami perpecahan antar manusia, agama, dan budaya.

\section{Bentuk-bentuk upaya PKPT IPNU IPPNU dalam pencegahan radikalisme di kampus IAIN Jember}

Berdasarkan temuan data dilapangan sesuai dengan teori diatas dari beberapa analisis data upaya PKPT IPNU IPPNU IAIN Jember dalam pencegahan radikalisme di IAIN Jember sebagai wadah menyebarkan syiar Islam Ahlussunnah wal jama'ah, dan sebagai wadah ukhwah Islamiah kaderisasi keilmuan untuk mempersiapkan kader-kader bangsa diantaranya melalui kegiatan progam jangka pendek dan jangka panjang. Progam jangka panjang yaitu dilakukan setiap 1 tahun sekali seperti mengadakan MAKESTA, LAKMUD, sholawatan, peringatan hari besar seperti Isra'Mi'roj, ziarah ke makam para wali. Dan progam jangka pendek. Kajian rutinan ini biasa dilakukan setiap malam jum'at jam 19.00 -21.00 tempat menyesuaikan dengan tema, kegiatan mengkaji kitab Arbain Nawawi, dibimbing oleh ustad Kholil, hari jum'at selanjutnya membahas mengenai sejarah 


\section{AL- ADABIYAH: Jurnal Pendidikan Agama Islam}

NU dan tokoh pendiri NU Kh.Hasyim Asyari. Oleh rekanita Maulida Cindi Magdalena selaku demisioner PKPT IPNU IPPNU IAIN Jember. hari jum'at selanjutnya membahas tentang asal asul radikalisme, di ajar oleh gus Samsul Huda. jadi kegiatan tersebut menyesuaikan tema dan kondisi yang ada, apabila pembina tidak dapat mengisi kajian maka pengurus dari PC Jember siap untuk mengisi kajian malam jum'at agar kegiatan dapat berjalan dengan lancar dan mengenai tema bisa menyesuaikan dengan isu-isu yang viral.

Hasil temuan diatas sesuai dengan tujuan IPNU IPPNU yaitu melakukan usaha-usaha antara lain pertama, menghimpun dan membina pelajar dalam wadah organisasi IPNU. Kedua, mempersiapkan kader-kader pemimpin militan yang berwawasan intelektual dan berjiwa spiritual sebagai penerus perjuangan bangsa. Ketiga mengusahakan tercapainya tujuan organisasi dengan menyusun landasan progam perjuangan sesuai dengan perkembangan masyarakat. Keempat, mengusahakan jalinan komunikasi dan kerjasama progam dengan pihak lain selama tidak merugikan organisasi (Hazin, 2019: 13).

Sebagai organisasi kepemudaan yang berada di bawah naungan Nahdlatul Ulama (NU) khusunya IPNU IPPNU harus mampu merawat dan menjaga Ahlus Sunnah Wal Jamaah (ASWAJA) yang telah dibawa oleh KH. Hasyim Asy'ari karena semenjak pemrintahan orde baru tumbang paham Aswaja mulai terpengaruh oleh kelompok gerakan radikal yang bukan hanya akan merusak paham aswaja namun juga akan merusak sistem ketatanegaraan Indonesia.

\section{Faktor pendukung dan penghambat upaya PKPT IPNU IPPU dalam pencegahan radikalisme di kampus IAIN Jember}

Berdasarkan hasil yang dieproleh dilapangan faktor pendukung internal antara anggota, pengurus, pembina dan pelaksanaan kegiatan yaitu sering melakukan kerja sama saling komunikasi dari pengurus ke pembina, sedangkan faktor penghambat kurang saling komunikasi antara pengurus dengan anggota sehingga pertanggung jawaban pengurus kurang.

Faktor pendukung eksternal Mempunyai bascampe untuk tempat diskusi, memanfaatkan media sebagai sarana dakwah seperti lomba kepenulisan dan menyebarkan famlet ketika ada kegiatan, serta menyebarkan qoutes bijak di media sosial. Faktor penghambatnya sarana prasarana belum mendukung karena 


\section{AL- ADABIYAH: Jurnal Pendidikan Agama Islam}

bascampe jauh dari kampus dan peralatan belum lengkap ketika akan melaksanakan kegiatan harus pinjam

Dari sarana prasarana yang mendukung dari kampus sendiri yaitu gedung, disetiap kelas ada papan tulis sehingga mempermudah pemateri ketika menjelaskan. Tempatnya kondisional. kegiatan dapat dilaksanakan di depan gedung FTIK dan serambi masjid.

Hasil temuan diatas sesuai dengan teori bahwa faktor internal yaitu faktor yang berada pada diri sendiri yang mempengaruhi proses dan hasil belajar, sedangkan faktor eksternal yaitu faktor yang berasal dari luar diri mahasiswa baik dari lingkungan atau instrumental. Berdasarkan penjelasan setiap mahasiswa mengalami kendala masing-masing saat proses kegiatan baik dari internal dan eksternal (Sukmawati, t.t.: 144).

Peneliti dapat menarik kesimpulan bahwa faktor penghambatnya terkadang tidak dapat pinjaman gedung, dan masalah pembiayan tidak punya donatur tetap, meskipun adanya khas akan tetapi dari temen-temen sendiri jarang ada yang membayar, skretariat jauh tempatnya, sehingga barang-barang masih dititipkan ke teman-teman. Kemudian ketika pemateri tidak dapat mengisi kajian dari pengurus harus siap mengisi, bisa mendatangkan orang-orang PC Jember untuk menggantikan pemateri. Dari pengurus dan anggota belum tahu cara mencari bakat apapun yang mereka dapat, sehingga banyak keinginan dan aktivitas yang masih mereka lakukan sehingga ada beberapa yang tidak aktif karena mengikuti kegiatan lain.

\section{Kesimpulan}

1. PKPT IPNU IPPNU dalam mengidentifikasi radikalisme di IAIN Jember antara lain ciri cirinya yaitu orang yang menganggap dirinya paling baik dan benar sendiri, menegakkan khilafah Islamiyah, berfikir tekstual, tidak menghargai perbedaan, tidak memandang keberagamaan, menolak moderasi agama, anti NKRI dan Pancasila. tindakan radikalisme di kalangan mahasiswa IAIN Jember masih belum terlihat akan tetapi dalam ranah pemikiran tentang keyakinan dalam pemahaman individu ada tetapi tidak terbuka sifatnya tertutup. ditemukannya beberapa mahasiswa yang mengikuti kajian diluar kampus kajian yang berfaham HTI. 


\section{AL- ADABIYAH: Jurnal Pendidikan Agama Islam}

2. Bentuk kegiatan yang dilakukan PKPT IPNU IPPNU IAIN Jember dalam pecegahan radikalisme melaksanakan progam kegiatan jarak panjang dilakukan setiap 1 tahun sekali mengadakan MAKESTA, (masa kesetian anggota) LAKMUD (latihan kader muda), Sholawatan bersama, peringatan hari besar seperti Isra' Mi'roj, ziarah ke makam para wali. progam jangka pendek mahasiswa mengaji yaitu pengantin baru (pengajian rutin pembahasan baru) setiap malam jum'at tahlilan, tiba'an, kajian mengenai kitab Arbain Nawawi, Ke-Nuan, membahas isu-isu yang telah viral.

3. Faktor pendukung internal antara anggota, pengurus, pembina sering melakukan kerja sama saling komunikasi. Faktor penghambat internal, kurang saling komunikasi antara pengurus dengan anggota, pembiayaan sangat minim. Faktor pendukung eksternal mempunyai bascampe, gedung, kelas, serambi Masjid. media sebagai famlet kegiatan, dan menyebarkan qoutes bijak di media sosial. Faktor penghambatnya Eksternal tidak dapat pinjaman gedung, bascampe jauh dari kampus.

\section{Referensi}

Asrori, Ahmad. 2015. "Radikalisme Di Indonesia antara historis dan Antropisitas Studi Agama dan pemikiran Islam", 9(2), 260.

Haris, Abdul Qodir. (2018) Fenomena Pemakaian Cadar dalam persepektif Pendidikan Islam. IAIN Jember.

Hazin, Mufarrihul. (2019) Hasil Kongres XIX Ikatan Pelajar Nahdlatul Ulama.Jakarta: Lembaga Pers.

Larasati, Anggi Dwi. (2018) "Peranan Lembaga Kemahasiswaan Dalam Menangkal Radikalisme. Universitas Lampung.

Miles, M.B., M.A. Huberman, and Jhonny Saldana (2013).Qualitatife Data Analisis A Methods Soursbook. California: SAGE Plublication.

Munip, Abdul. (2012) . Menangkal radikalisme di sekolah, Yogyakarta." Pendidikan Islam 2(2), 162.

Musthofa, Imam.(2012). Terorisme antara aksi dan Reaksi (gerakan Islam Radikal sebagai Respon terhadap Imperialisme Modern)" Siwo Metro Lampung 15(1), 67.

Muzadi, Abdul Muchith. (2006). NU Dalam Persepektif Sejarah dan Ajaran. Surabaya: Khalista. 


\section{AL- ADABIYAH: Jurnal Pendidikan Agama Islam}

Nawangsari, Dyah. (2009). Kecenderungan open minded (keterbukaan berfikir) di PTAI dalam perspektif stakeholder kampus STAIN jember. Jember: STAIN Jember.

Peraturan Menteri Pendidikan dan Kebudayaan, Nomer 5 Tahun 2018 Tentang Pemberantasan Tindak Pidana Korupsi.

Peraturan Menteri Pendidikan dan Kebudayaan, Nomer 5 Tahun 2018 Tentang Pemberantasan tindak pidana korpusi. Pasal 13.

Saifudin. (2011). "Radikalisme Islam di Kalangan Mahasiswa", Universitas Islam Sunan Kalijaga Yogyakarta.

Sugiono. (2017). Metode penelitian pendidikan kuantitatif, kualitatif dan R\&D Bandung: Alfabeta.

Sukmawati. (t,t) Analisis Faktor- Faktor penghambat dalam proses pembelajaran trigonometri.

Susanto, "22 Persen Mahasiswa Universitas Jember Terpapar Radikalisme", https://www.medcom.id/pendidikan/news-pendidikan/GN1YwRmb-22-persenmahasiswa-universitas-jember-terpapar-radikalisme (21 November 2019).

Ulum, Miftahul. (2017). tradisi dakwah Nahdlatul Ulama di Indonesia. jurnal keislamaan dan kemasyarakatan, 1 no 1.

Van Bruinessan, Martin. (2004). NU Muda Kaum Progesif dan Sekularisme Baru. Jakarta: Penerbit Erlangga.

Wahab, Abdul Jamil. (2019). Islam Radikal dan Moderat. Jakarta: PT Elex Media Komputindo.

Yusuf, Muri. (2014). Metode Penelitian Kuantitatif, Kualitatif, dan Penelitian Gabungan. Jakarta: Kencana.

Zuhri, Saefudin. (2017). Deradikalisasi Terorisme. Jakarta: Daulat Press Jakarta. 